\title{
COMPARATIVE ANALYSIS OF GOVERNMENT DEBT IN THE EUROPEAN UNION'S MEMBER STATES, 2000-2013
}

The paper presents a detailed comparative analysis of the evolution of government debt stocks in the E.U. Member States at the end of the period 31.12.2000-31.12.2013 from the point of view of the share of these debts in the GDP, with a focus on six groups of the E.U. Member States (E.U.-28 countries, E.U.-27 countries, Euro area-18 countries, Euro area-17 countries, Non Euro area-10 countries, Non Euro area-11 countries), on the E.U. Member States with a government debt stock share above or below 60\% of the GDP at 31.12.2013, on the Member States which recorded very large deviations of the government debt stocks and of those stocks' shares in PIB in the analyzed period or which recorded a decrease in government debt stock shares in PIB - and, separately, on Romania as well.

Key words: government debt, government debt stock, government debt accumulation, public indebtedness, government debt stock increase, gross domestic product, absolute deviation, relative deviation, times of increases, government debt crisis

\section{Introduction}

Based on data taken from Eurostat and on the author's own calculations (reproduced in the annexes no. 1, 2, 3, 4, 5 and 6) a detailed analysis has been carried out for the evolution of the government debt stock within a period of 14 successive years - from 01.01.2000 to 31.12.2013.

This analysis comprises the evolution of the government debt stock share in the GDP at the end of the studied 14 year-period with the benchmark limit of $60 \%$ of the GDP - determined as a convergence criterion to the Economic and Monetary Union of the European Union through the Maastricht Treaty [1], as well as the evolution of the absolute government debt stocks at the end of the years (and at the end of the 56 quarters as well - in the case of Romania).

Professor Ioan Talpoş, PhD, West University of Timisoara, Romania, e-mail: ioan.talpos@ gmail.com, ioan.talpos@e-uvt.ro 
The analysis focused on the following economic areas:

I. The European Union with 28 Member States;

II. The European Union with 27 Member States;

III. The Euro area with 18 Member States;

IV. The Euro area with 17 Member States;

V. The Non Euro area with 10 Member States;

VI. The Non Euro area with 11 Member States;

VII. The European Union's Member States which:

a) have registered government debt stock shares above $60 \%$;

b) have significant deviations of government debt stock shares at 31.12.2013, which, in relative expression, exceeded 50\% (Ireland, Slovenia, Portugal, United Kingdom, Croatia, Cyprus, Greece, France and Spain);

c) have registered important increases (3 times) of the government debt stock size during the analyzed period (Latvia, Luxembourg, Romania, Estonia, Czech Republic, Ireland, Lithuania, Slovenia, Slovakia, Croatia, Portugal, Poland, Cyprus);

d) have registered significant relative deviations - above $100 \%$ - of government debt stock shares at 31.12.2013 (Luxembourg, Ireland, Latvia, Slovenia, Portugal, Czech Republic, United Kingdom);

e) have registered decreases of the government debt stock share at the end of the analyzed period (Bulgaria, Sweden and Denmark);

f) have government debt stock shares below 60\% of the GDP at 31.12.2013; these 11 Member States are: Estonia (10,1\%), Bulgaria (18,9\%), Luxembourg (23,5\%), Latvia (38,0\%), Romania (38,1\%), Sweden (39,1\%), Lithuania (39,4\%), Czech Republic (45,6\%), Denmark (45,8\%), Slovakia (55,7\%) and Finland (58,2\%).

VIII. Romania.

2. The results of the comparative analysis

Taking into consideration the evolution of the government debt stock shares in the GDP at the end of the years in analyzed period, the absolute value (million Euros) of these stocks, as well as the absolute value of the annual GDP, the outcome of the detailed analysis is:

1. At the beginning of the analyzed period (31.12.2000), as figure no. 1 shows, the following have registered a government debt stock share above $60 \%$ of the GDP:

- $\quad$ the total for the EU-28 countries (62.7\%);

- the total for the EU-27 countries (62.7\%);

- $\quad$ the total for the Euro area-18 countries (70.2\%);

- the total for the Euro area -17 countries (70.3\%); 
- 6 Member States of the E.U.-28 countries, which we enumerate in the descending order of this share: Italy (108.6\%), Belgium (107.8\%), Greece (103.4\% at 31.12.2000), Bulgaria (72.5\%), Austria (66.2\%) and Germany (60.2\%).

Both E.U.-28 and E.U.-27, both Euro areas and the 6 states with government debt stock shares above 60\% of the GDP at 31.12.2000 are shown in figure no. 1 .

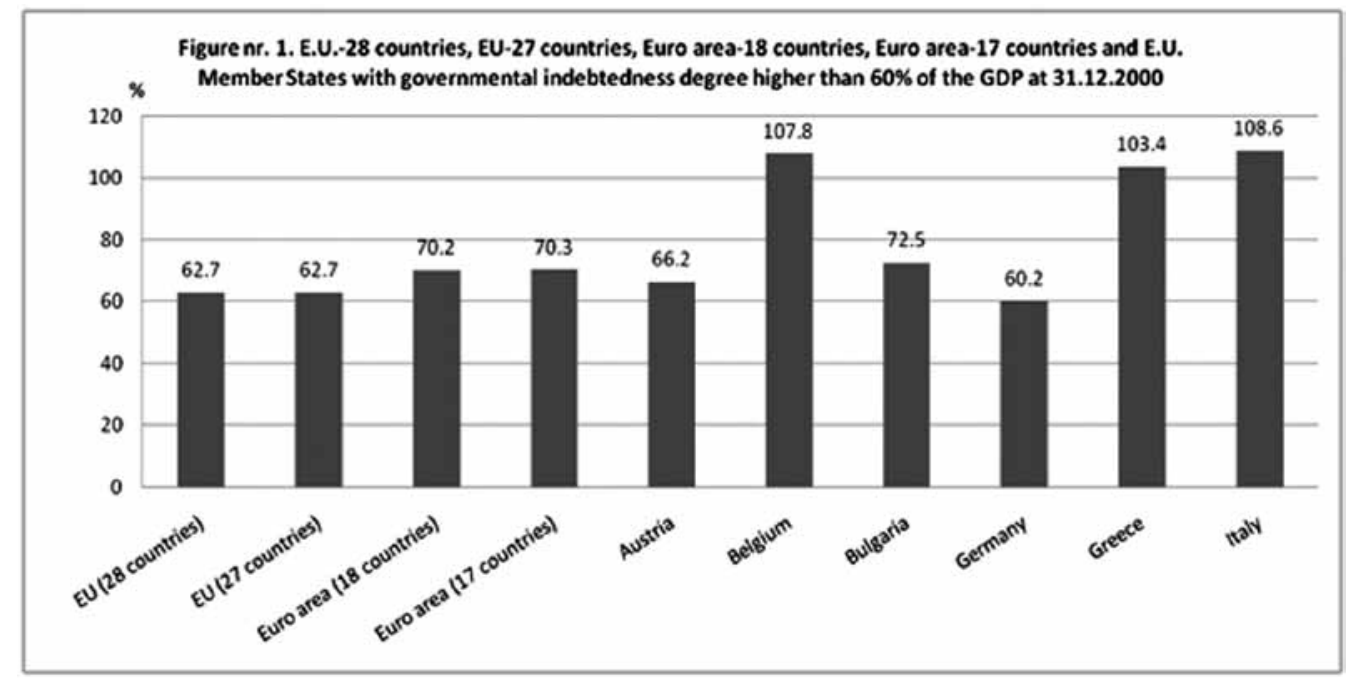

2. At the end of the analyzed period (31.12.2013), as shown in Figure no. 2, the following have registered actual amounts of government debt stock above $60 \%$ of the GDP:

- $\quad$ the entire E.U.-28 countries (90.2\%);

- the entire E.U.-27 countries (90.2\%);

- the Euro area-18 countries (96.2\%);

- $\quad$ the Euro area-17 countries (96.4\%);

- $\quad$ the Non Euro area-10 countries (73.2\%);

- $\quad$ the Non Euro area-11 countries (73.3\%);

- in 16 Member States of the E.U.-28 countries, which we present in table no. 1 . 


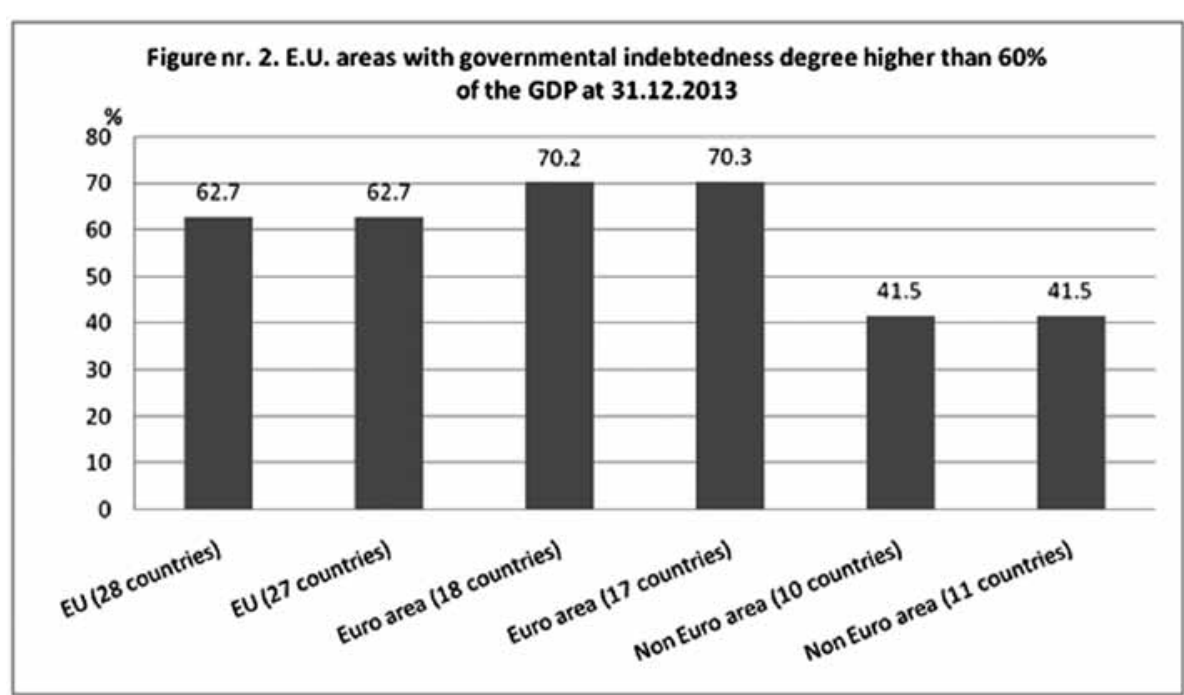

In the European Union with 27 Member States, respectively 28 Member States (although this number of Member States can be referred to only since 01.01.2007, respectively from 01.07.2013), the government debt stocks share in the GDP went upward - from $62.7 \%$ to $90.2 \%$ with an absolute deviation of +27.5 percentage points and a relative growth of $43.9 \%$, i.e. 1.44 times (see the results in annex no. 6).

Expressed as an absolute value, the total government debt stocks showed an increase at 31.12.2013 with 6,006,364.4 million Euros at the level of E.U.-28 countries, and respectively with 5,982,951.0 million Euros at the level of E.U.-27 countries, doubling the size of these stocks compared to 31.12.2000 (see annex no. 4).

Within the Euro area with 18 and 17 Member States, there was also an increase of the government debt stocks share in the GDP - from 70.2\% (70.3\%) to $96.2 \%$ (96.4\%), with a deviation of 26 (26.1) percentage points and a relative growth of $37 \%$ (37.1\%).

The absolute deviations of the government debt stocks in the Euro area account for $+4,470,271$ million Euros (EA-18 countries), respectively for $+4,462,406$ million Euros (EA-17 countries).

The increasing evolution was even more obvious for the group of 10, respectively 11 Non-Euro area Member States - from 41.5\% to 73.2\% (73.3\%), with an absolute deviation of 31.7 (31.8) percentage points and a relative growth of $76.4 \%$ (76.6\%).

The absolute deviations of the government debt stocks at 31.12.2013 represented $+1,520,545$ million Euros (NEA-10 countries), and respectively $+1,543,545$ million Euros (NEA-11 countries), with more significant relative growths compared to those in the Euro area $(+151.5 \%$ and $+152.4 \%)$.

The analysis went further with the situation of EU-28 countries Member States which are presented in table no. 1, in the descending order of government debt stock shares at the end of the analyzed period, as suggestively shown in figure no. 3 . 
Comparative analysis of government debt in the European union's member... 87

Table 1: The situation of the E.U.-28 countries Member States with a government debt stock share above 60\% in the GDP at 31.12.2013

\begin{tabular}{|c|l|r|r|r|r|r|r|}
\hline \multirow{2}{*}{ No. } & \multirow{2}{*}{$\begin{array}{c}\text { Member } \\
\text { State }\end{array}$} & $\begin{array}{r}\text { The government debt } \\
\text { stock share of the GDP } \\
(\%) \text { at: }\end{array}$ & \multicolumn{2}{c|}{$\begin{array}{r}\text { Deviations in the analyzed } \\
\text { period of time }\end{array}$} & \multicolumn{2}{c|}{$\begin{array}{c}\text { Deviations from the } \\
60 \% \text { limit of the GDP }\end{array}$} \\
\cline { 2 - 8 } & & 31.12 .2000 & 31.12 .2013 & Absolute (pp) & Relative (\%) & 31.12 .2000 & 31.12 .2013 \\
\hline 1 & Greece & 103.4 & 175.3 & +71.9 & +69.5 & +43.4 & +115.3 \\
\hline 2 & Italy & 108.6 & 132.7 & +24.1 & +22.2 & +48.6 & +72.7 \\
\hline 3 & Portugal & 50.7 & 132.3 & +81.6 & +160.9 & -9.3 & +72.3 \\
\hline 4 & Ireland & 37.0 & 131.4 & +94.4 & +255.1 & -23.0 & +71.4 \\
\hline 5 & Cyprus & 59.6 & 112.2 & +52.6 & +88.3 & -0.4 & +52.2 \\
\hline 6 & Belgium & 107.8 & 108.0 & +0.2 & +0.2 & +47.8 & +48.0 \\
\hline 7 & France & 57.5 & 94.6 & +37.1 & +64.5 & -2.5 & +34.6 \\
\hline 8 & United & 41.1 & 94.4 & +53.3 & +129.7 & -18.9 & +34.4 \\
\hline 9 & Spain & 59.4 & 94.4 & +35.0 & +58.9 & -0.6 & +34.4 \\
\hline 10 & Austria & 66.2 & 83.7 & +17.5 & +26.4 & +6.2 & +23.7 \\
\hline 11 & Hungary & 56.1 & 79.3 & +23.2 & +41.3 & -3.9 & +19.3 \\
\hline 12 & Germany & 60.2 & 78.9 & +18.7 & +31.1 & +0.2 & +18.9 \\
\hline 13 & Croatia & 38.9 & 75.9 & +37.0 & +95.1 & -21.1 & +15.9 \\
\hline 14 & Netherlands & 53.8 & 73.2 & +19.4 & +36.1 & -6.2 & +13.2 \\
\hline 15 & Malta & 53.9 & 72.2 & +18.3 & +33.5 & -6.1 & +12.2 \\
\hline 16 & Slovenia & 26.3 & 72.1 & +45.8 & +174.1 & -33.7 & +12.1 \\
\hline
\end{tabular}

Sources of data: Eurostat, on 14.11.2014 (Annex no. 4) and author's own calculations

The ability to support the government debt differs undoubtedly from one Member State to another and the motivation of government indebtedness is also different. But the significant increase above the limit of $60 \%$ of the GDP determines us to consider that the 16 Member States from the previous table make up the group of Member States undergoing a government debt crisis inside the European Union.

Among the 16 E.U. Member States referred to, 11 had government debt stock shares below $60 \%$ of the GDP at the beginning of the analyzed period (01.01. $2000)$ and we list them in ascending order of their share: Slovenia (26.3\%), Ireland (37.0\%), Croatia (38.9\%), United Kingdom (41.1\%), Portugal (50.7\%), Malta (53.9\%), Hungary (56.1\%), France (57.5\%), Spain (59.4\%), Cyprus (59.6\%) - fulfilling at the time the criterion for accessing the Economic and Monetary Union (EMU) established by Maastricht Treaty. 


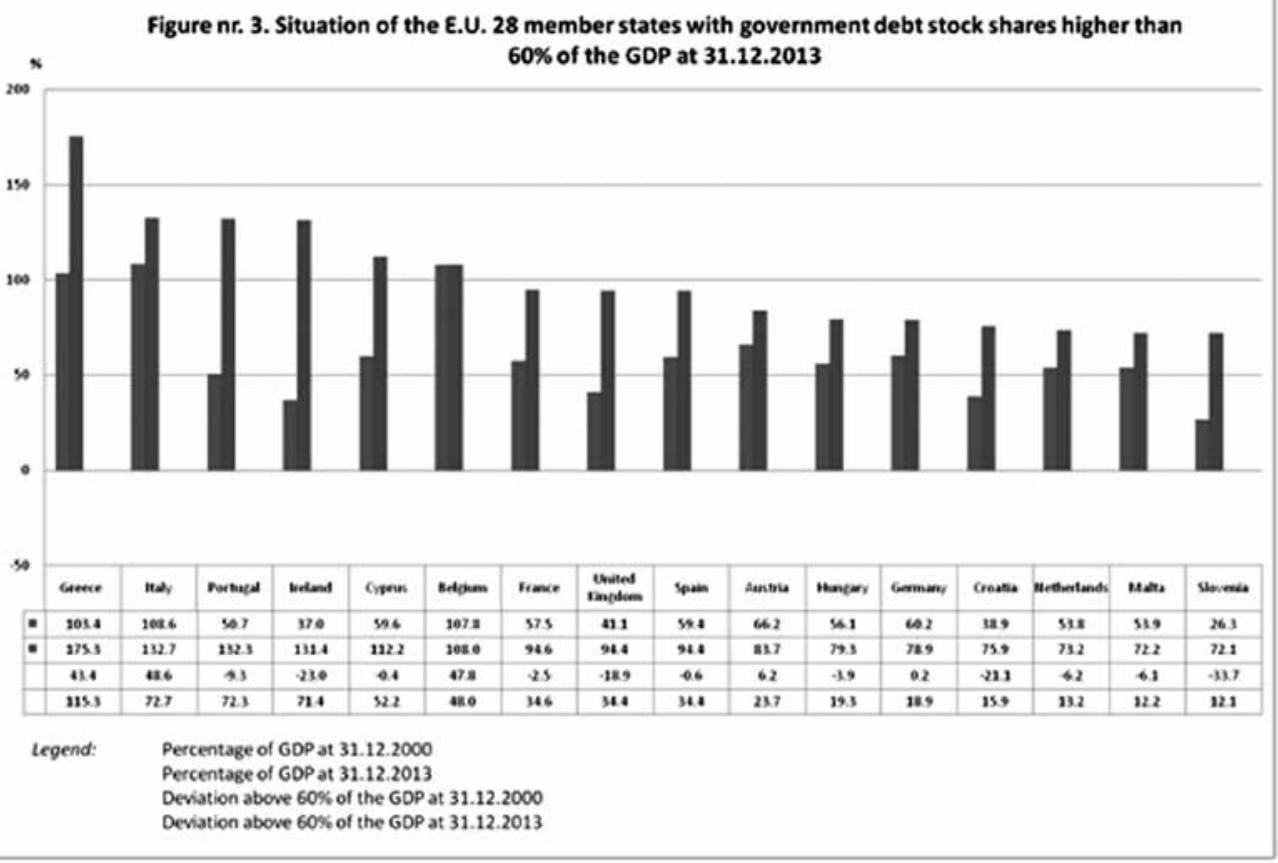

As one can notice, the deviations above $60 \%$ limit of the GDP differ significantly from one Member State to another - ranging from +115.3 percentage points for Greece to 12.1 percentage points for Slovenia.

3. Obviously a separate analysis could be carried out for 9 Member States out of this group of 16 - in their case the relative deviation of the government debt stock share exceeded 50\% at 31.12.2013. We list these Member States in descending order of their relative deviation: Ireland (+255.1\%), Slovenia (+174.1\%), Portugal (+160.9\%), United Kingdom (+129.7\%), Croatia (+95.1\%), Cyprus (+88.3\%), Greece (+69.5\%), France (+64.5\%) and Spain (+58.9\%).

The data of the analysis for these 9 Member States are presented in table no. 2 and illustrated through figures no. 4 and 5. 
Table 2: The group of 9 E.U.-28 countries Member States with significant disparities between government debt stock shares in GDP, registered in the period 2000-2013 and between absolute sizes of government debt stocks

\begin{tabular}{|c|c|c|c|c|c|c|c|c|c|}
\hline \multirow[t]{2}{*}{ No. } & \multirow{2}{*}{$\begin{array}{c}\text { Member } \\
\text { State }\end{array}$} & \multicolumn{2}{|c|}{$\begin{array}{c}\text { Government debt } \\
\text { stock share in GDP } \\
(\%) \text { at: }\end{array}$} & \multicolumn{2}{|c|}{ Deviation } & \multicolumn{2}{|c|}{$\begin{array}{c}\text { Government debt } \\
\text { stocks (mill. Euros) at: }\end{array}$} & \multirow{2}{*}{\begin{tabular}{|c|} 
Absolute \\
deviation \\
(mill. Euros)
\end{tabular}} & \multirow{2}{*}{$\begin{array}{l}\text { Times of } \\
\text { increases of } \\
\text { government } \\
\text { debt stock }\end{array}$} \\
\hline & & 31.12 .2000 & 31.12 .2013 & $\begin{array}{c}\text { absolute } \\
\text { (pp) }\end{array}$ & \begin{tabular}{|c|} 
relative \\
$(\%)$
\end{tabular} & 31.12 .2000 & 31.12 .2013 & & \\
\hline 1 & Ireland & 37.0 & 131.4 & +94.4 & +255.1 & $39,049.1$ & $215,550.0$ & $+176,455.9$ & 5.51 \\
\hline 2 & Slovenia & 26.3 & 72.1 & +45.8 & +174.1 & $5,483.6$ & $25,428.1$ & $+19,944.5$ & 4.64 \\
\hline 3 & Portugal & 50.7 & 132.3 & +81.6 & +160.9 & $64,650.5$ & $219,225.0$ & $+154,584.5$ & 3.39 \\
\hline 4 & \begin{tabular}{|l|} 
United \\
Kingdom \\
\end{tabular} & 41.1 & 94.4 & +53.3 & +129.7 & $640,453.5$ & $1,792,797.2$ & $+1,152,343.7$ & 2.80 \\
\hline 5 & Croatia & 38.9 & 75.9 & +37.0 & +95.1 & $9,345.5$ & $32,758.9$ & $+23,413.4$ & 3.51 \\
\hline 6 & Cyprus & 59.6 & 112.2 & +52.6 & +88.3 & $5,930.9$ & $18,518.8$ & $+12,587.9$ & 3.12 \\
\hline 7 & Greece & 103.4 & 175.3 & +71.9 & +69.5 & $140,907.6$ & $319,133.0$ & $+178,225.4$ & 2.26 \\
\hline 8 & France & 57.5 & 94.6 & +37.1 & +64.5 & $867,961.1$ & $1,949,475.0$ & $+1,081,513.9$ & 2.25 \\
\hline 9 & Spain & 59.4 & 94.4 & +35.0 & $\begin{array}{l}58.9 \\
\end{array}$ & $374,557.0$ & $966,181.0$ & $+591,624.0$ & 2.58 \\
\hline
\end{tabular}

Sources of data: Eurostat (Annexes 3, 4, 5, 6) and author's own calculations

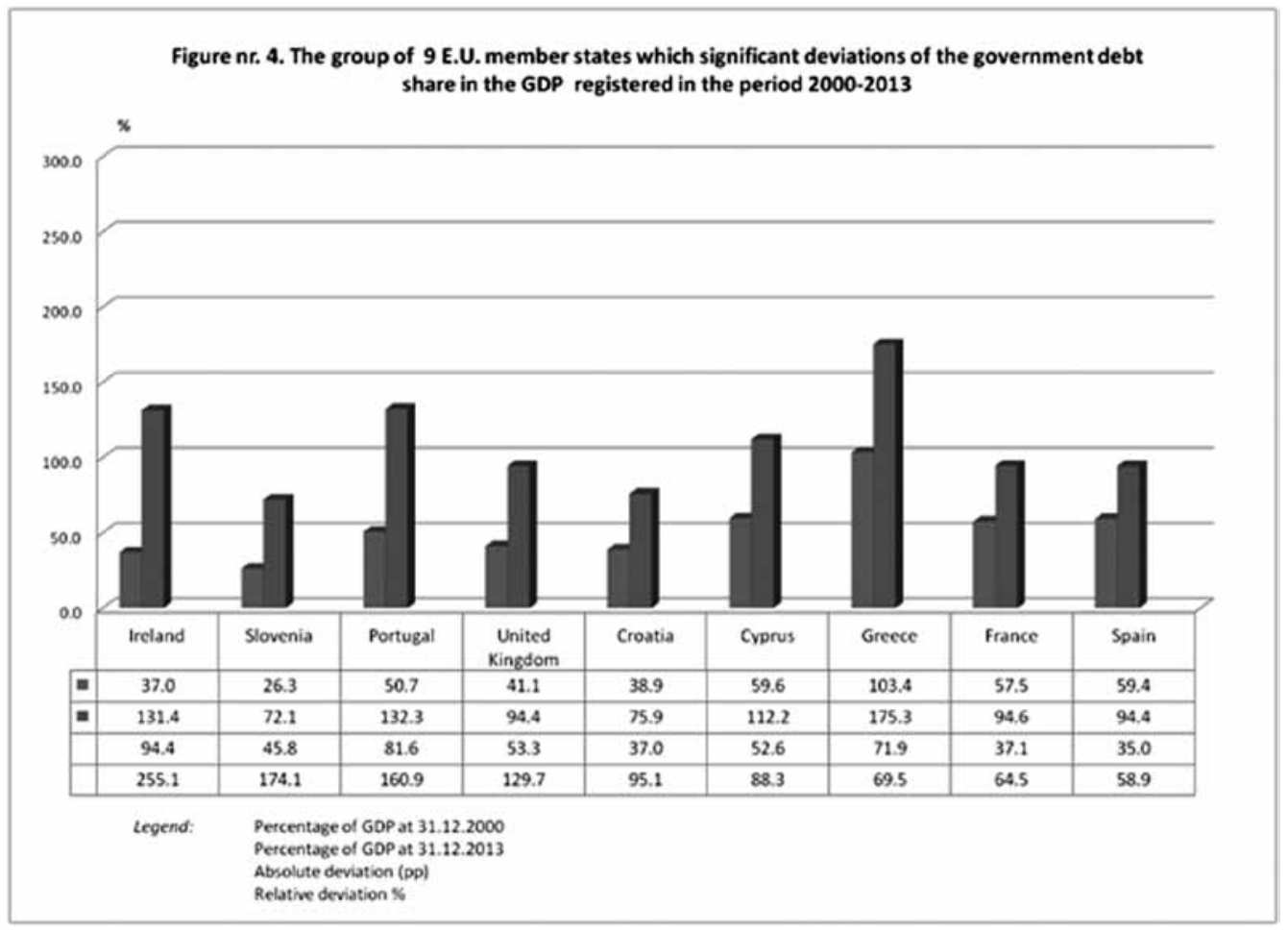




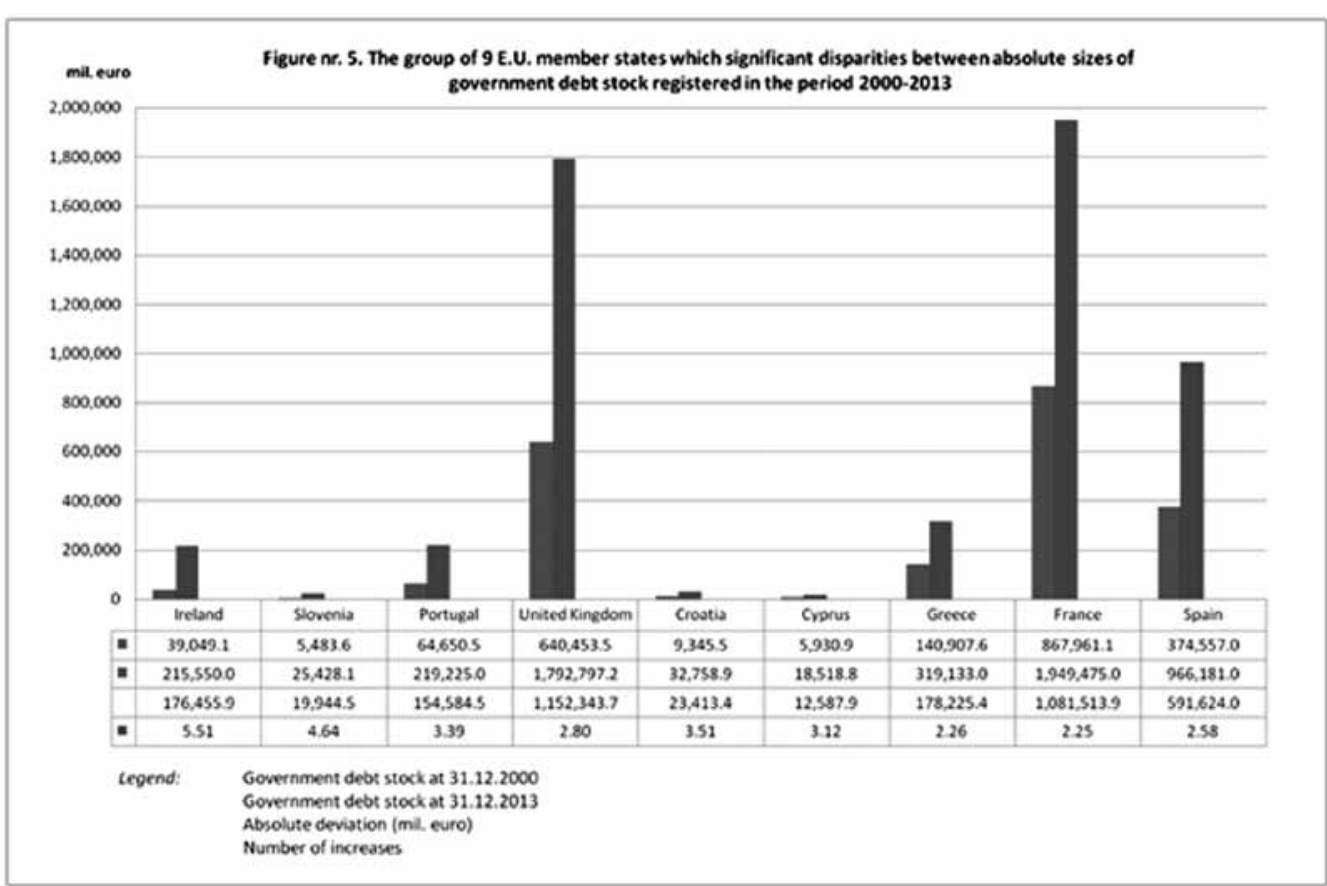

Depending on the size of the analyzed Member States, the absolute deviations of the government debt stocks differ significantly from one Member State to another - ranging from $+1,152,343.7$ million Euros in the case of the United Kingdom to $+12,587.9$ million Euros in the case of Cyprus, and the times of increases of government debt stocks registered in these 14 years is between 5.51 times in the case of Ireland and 2.25 times in the case of France.

4. Very large increases in the size of the government debt stocks during the 14 years of the analyzed period (more than 3 times) were registered by $13 \mathrm{Mem}$ ber States of the EU-28 countries, and the analysis results are shown in table no. 3 , with graphic illustration in figure no. 5 .

Table 3: E.U.-28 countries Member States with very large increases (more than 3 times) of government debt stocks

\begin{tabular}{|c|c|c|c|c|c|c|c|c|}
\hline \multirow[t]{2}{*}{ No. } & \multirow[t]{2}{*}{ Member State } & \multicolumn{2}{|c|}{$\begin{array}{c}\text { Government debt } \\
\text { stocks (mill. Euros) at: }\end{array}$} & \multicolumn{2}{|c|}{ Deviation } & \multirow{2}{*}{$\begin{array}{c}\text { No. of } \\
\text { increases } \\
\text { of gov.debt } \\
\text { stock }\end{array}$} & \multicolumn{2}{|c|}{$\begin{array}{l}\text { Government debt stock } \\
\text { share in the GDP at: }\end{array}$} \\
\hline & & 31.12 .2000 & 31.12 .2013 & $\begin{array}{c}\text { in absolute } \\
\text { numbers } \\
\text { (mill. Euros) }\end{array}$ & $\begin{array}{c}\text { relative } \\
(\%)\end{array}$ & & 31.12 .2000 & 31.12 .2013 \\
\hline 1 & Latvia & $1,011.0$ & $8,876.0$ & $+7,865.0$ & +777.9 & 8.78 & 12.4 & 38.0 \\
\hline 2 & Luxembourg & $1,410.3$ & $10,668.9$ & $+9,258.6$ & +656.5 & 7.57 & 6.2 & 23.5 \\
\hline 3 & Romania & $7,532.8$ & $54,170.0$ & $+46,637.2$ & +619.1 & 7.19 & 22.5 & 38.1 \\
\hline 4 & Estonia & 315.6 & $1,887.5$ & $+1,571.9$ & +498.1 & 5.98 & 5.1 & 10.1 \\
\hline
\end{tabular}


Comparative analysis of government debt in the European union's member... 91

\begin{tabular}{|r|l|r|r|r|r|r|r|r|}
\hline 5 & $\begin{array}{l}\text { Czech } \\
\text { Republic }\end{array}$ & $11,525.8$ & $68,152.2$ & $+56,626.4$ & +491.3 & 5.91 & 17.8 & 45.6 \\
\hline 6 & Ireland & $39,094.1$ & $215,550.0$ & $+176,455.9$ & +451.4 & 5.51 & 37.0 & 131.4 \\
\hline 7 & Lithuania & $2,912.1$ & $13,636.5$ & $+10,724.4$ & +368.3 & 4.68 & 23.6 & 39.4 \\
\hline 8 & Slovenia & $5,483.6$ & $25,428.1$ & $+19,944.5$ & +363.7 & 4.64 & 26,3 & 72.1 \\
\hline 9 & Slovakia & $10,753.4$ & $40,178.4$ & $+29,425.0$ & +273.6 & 3.74 & 50.3 & 55.7 \\
\hline 10 & Croatia & $9,345.5$ & $32,758.9$ & $+23,413.4$ & +250.5 & 3.51 & 38.9 & 75.9 \\
\hline 11 & Portugal & $64,640.5$ & $219,225.0$ & $+154,584.5$ & +239.1 & 3.39 & 50.7 & 132.3 \\
\hline 12 & Poland & $71,128.9$ & $222,926.4$ & $+151,797.5$ & +213.4 & 3.13 & 38.3 & 57.2 \\
\hline 13 & Cyprus & $5,930.9$ & $18,518.8$ & $+12,587.9$ & +212.2 & 3.12 & 59.6 & 112.2 \\
\hline
\end{tabular}

Sources of data: Eurostat (Annexes no. 3, 4) and author's own calculations

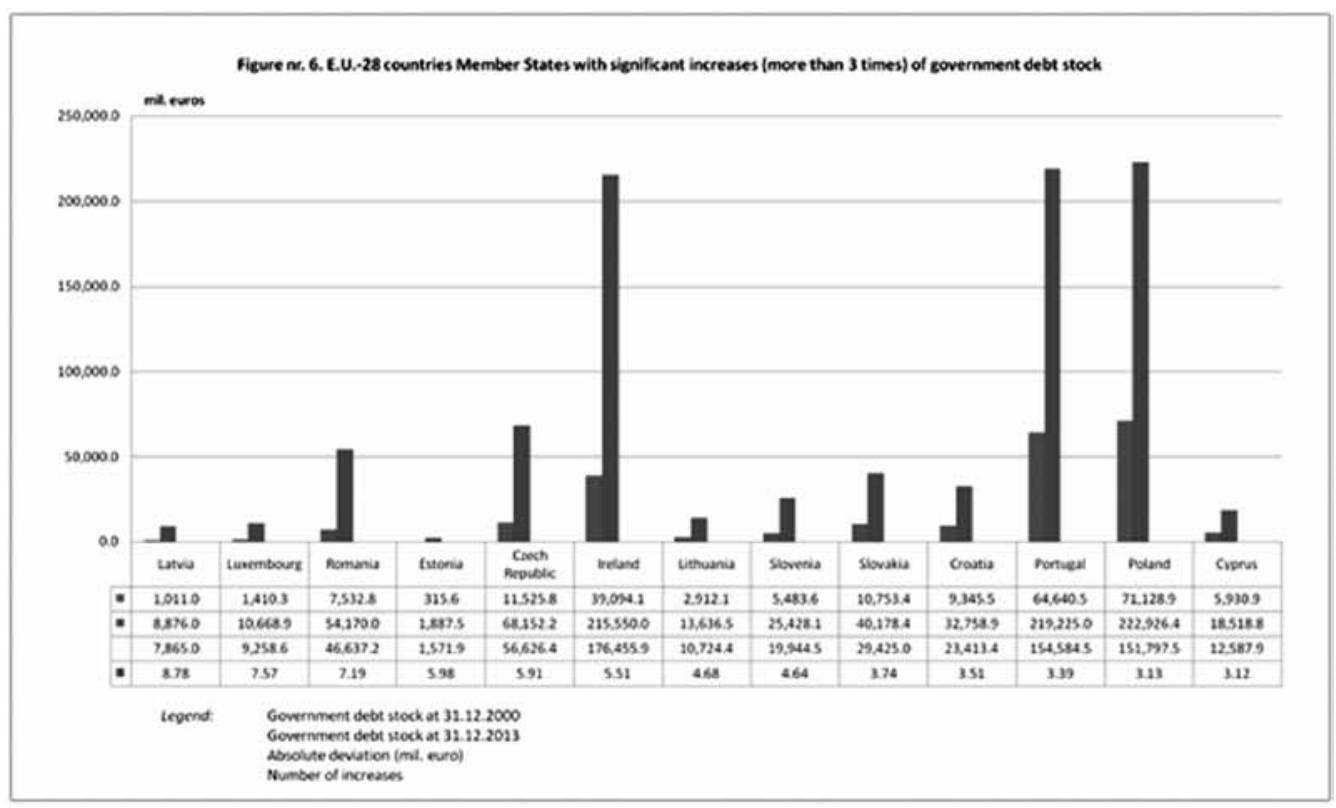

As one can notice, all the 13 Member States in the previous table had at 31.12.2000 a government debt stock share below 60\% of the GDP, but - by 31.12.2013 - 5 Member States entered the group of Member States with a government debt that exceeded $60 \%$ of the GDP. These states are in a descending order of their share: Portugal (132.3\%, from 50.7\%), Ireland (131.4\%, from $37.0 \%)$, Cyprus (112.2\%, from 59.6\%), Croatia (75.9\%, from $38.9 \%$ ) and Slovenia (72.1\%, from $26.3 \%)$.

The times of increases of the government debt stock at 31.12.2013 ranges from 8.78 for Latvia, to 3.12 for Cyprus, and the increase of the absolute government debt stock registers quite different values and ranges from 176,455.9 million Euros for Ireland to 1,571.9 million Euros for Estonia. 
5. A significant number of Member States inside the EU-28 having made up a group based on the evolution of the government debt stock share in the GDP registered considerable relative deviations of these shares which exceeded $100 \%$.

The data of this analysis are specified in table no. 4, with graphic illustration in figure no. 7 .

Table 4: EU-28 countries Member States with significant relative deviations (more than 100\%) of government debt stock shares in the GDP at 31.12.2013

\begin{tabular}{|c|c|c|c|c|c|c|}
\hline No. & Member State & Government & t stocks (\%) at: & Devi & tion & Times \\
\hline & & 31.12 .2000 & 31.12 .2013 & absolute (pp) & relative (\%) & $\begin{array}{l}\text { or snare } \\
\text { increases }\end{array}$ \\
\hline 1 & Luxembourg & 6.2 & 23.5 & +17.3 & +279.0 & 3.79 \\
\hline 2 & Ireland & 37.0 & 131.4 & +94.4 & +255.1 & 3.55 \\
\hline 3 & Latvia & 12.4 & 38.0 & +25.6 & +206.5 & 3.06 \\
\hline 4 & Slovenia & 26.3 & 72.1 & +45.8 & +174.1 & 2.74 \\
\hline 5 & Portugal & 50.7 & 132.3 & +81.6 & +160.9 & 2.61 \\
\hline 6 & Czech Republic & 17.8 & 45.6 & +27.8 & +156.2 & 2.56 \\
\hline 7 & $\begin{array}{l}\text { United } \\
\text { Kingdom }\end{array}$ & 41.1 & 94.4 & +53.3 & +129.7 & 2.30 \\
\hline
\end{tabular}

Sources of data: Eurostat (Annexes no. 5, 6) and author's own calculations

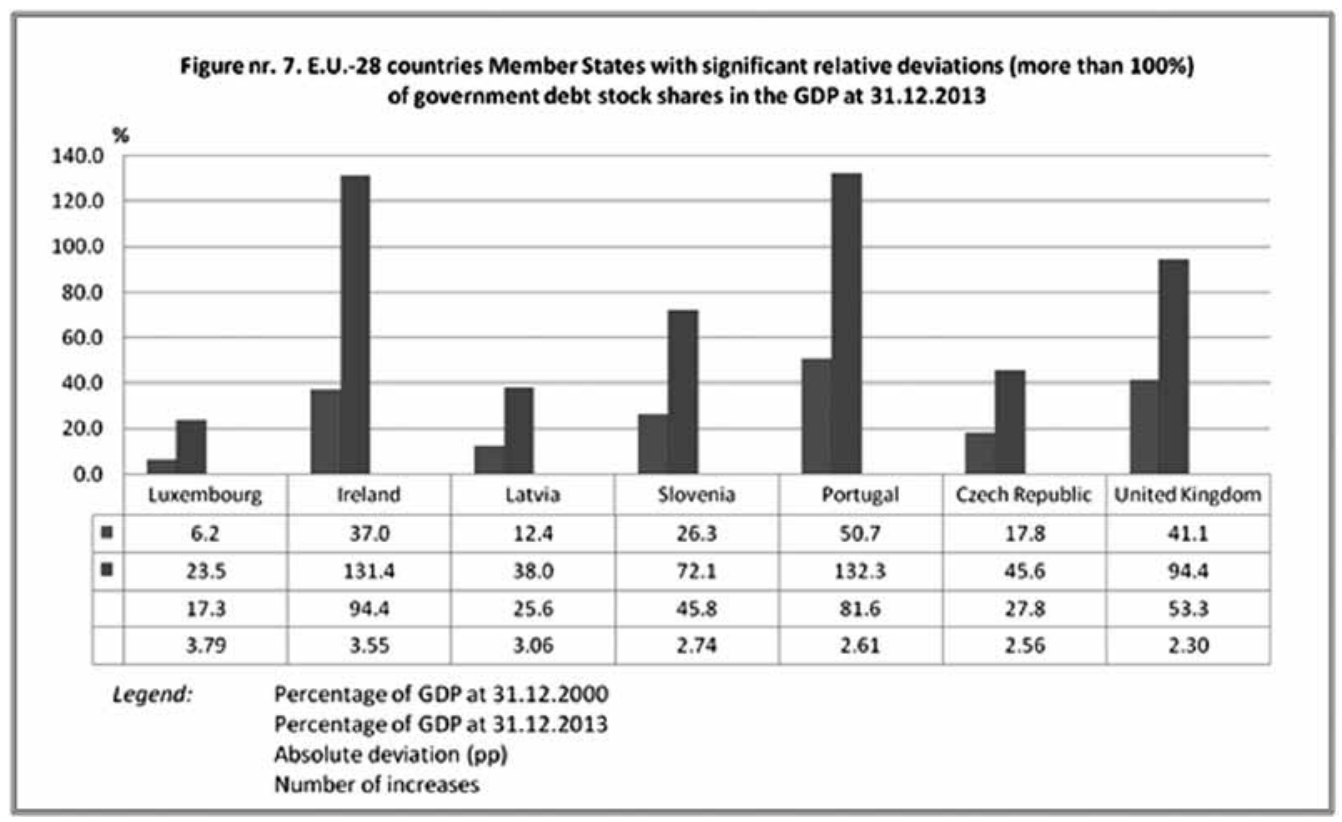


The variation interval of the relative deviations of the government debt stocks shares in the GDP at 31.12.2013 is very high, ranging from $+279.0 \%$ (Luxembourg) to $+129.7 \%$ (United Kingdom). As one can notice, at 31.12.2000 all 7 Member States had government debt levels below $60 \%$ of the GDP while at 31.12.2013 4 of these Member States exceeded this government debt level (Portugal 132.3\%, Ireland 131.4\%, United Kingdom 94.4\% and Slovenia 72.1\%), expanding the area of E.U. Member States with a government debt crisis.

6. Referring again to the group of the 16 E.U. Member States with government debt stocks shares above $60 \%$ of the GDP at 31.12.2013, one can see that only 5 of them had such levels of shares at 31.12.2000, namely (in descending order) Italy (108.6\%), Belgium (107.8\%), Greece (103.4\%), Austria (66.2\%) and Germany (60.2\%). In the remaining 11 E.U. Member States the shares were well below $60 \%$ of the GDP [Slovenia (-33.7\%), Ireland (-23.0\%), Croatia (-21.1\%) and United Kingdom (-18.9\%)], less below 60\% of the GDP [Portugal (-9.3\%), Netherlands $(-6.2 \%)$, Malta (-6.1\%), Hungary $(-3.9 \%)$ and France $(-2.5 \%)]$ or slightly below $60 \%$ of the GDP [Spain $(-0.6 \%)$ and Cyprus $(-0.4 \%)$ ].

7. According to the descending size of the relative deviation of the government debt stock share in the GDP at the end of the analyzed period, we further present the registered evolutions in the 11 Member States, by means of respective data in table no. 5 , with graphic illustration in figure no. 8 .

Table 5: EU-28 countries Member States with government debt stock shares below $60 \%$ of the GDP at 31.12.2000 and with significant relative increases of those shares at 31.12.2013

\begin{tabular}{|c|c|c|c|c|c|c|}
\hline \multirow[t]{2}{*}{ No. } & \multirow[t]{2}{*}{$\begin{array}{c}\text { Member } \\
\text { State }\end{array}$} & \multicolumn{2}{|c|}{$\begin{array}{l}\text { Government debt stock } \\
\text { share in the GDP (\%) at: }\end{array}$} & \multicolumn{2}{|c|}{$\begin{array}{c}\text { Deviations in the analyzed } \\
\text { time interval }\end{array}$} & \multirow{2}{*}{$\begin{array}{l}\text { Times of share } \\
\text { increases }\end{array}$} \\
\hline & & 31.12 .2000 & 31.12 .2013 & absolute (pp) & relative (\%) & \\
\hline 1 & Ireland & 37.0 & 131.4 & +94.4 & +255.1 & 3.55 \\
\hline 2 & Slovenia & 26.3 & 72.1 & +45.8 & +174.1 & 2.74 \\
\hline 3 & Portugal & 50.7 & 132.3 & +81.6 & +160.9 & 2.61 \\
\hline 4 & $\begin{array}{l}\text { United } \\
\text { Kingdom }\end{array}$ & 41.1 & 94.4 & +53.3 & +129.7 & 2.30 \\
\hline 5 & Croatia & 38.9 & 75.9 & +37.0 & +95.1 & 1.95 \\
\hline 6 & Cyprus & 59.6 & 112.2 & +52.6 & +88.3 & 1.88 \\
\hline 7 & France & 57.5 & 94.6 & +37.1 & +64.5 & 1.65 \\
\hline 8 & Spain & 59.4 & 94.4 & +35.0 & +58.9 & 1.59 \\
\hline 9 & Hungary & 56.1 & 79.3 & +23.2 & +41.3 & 1.41 \\
\hline 10 & Netherlands & 53.8 & 73.2 & +19.4 & +36.1 & 1.36 \\
\hline 11 & Malta & 53.9 & 72.2 & +18.3 & +33.5 & 1.33 \\
\hline
\end{tabular}

Sources of data: Eurostat (previous table no. 1) and author's own calculations 


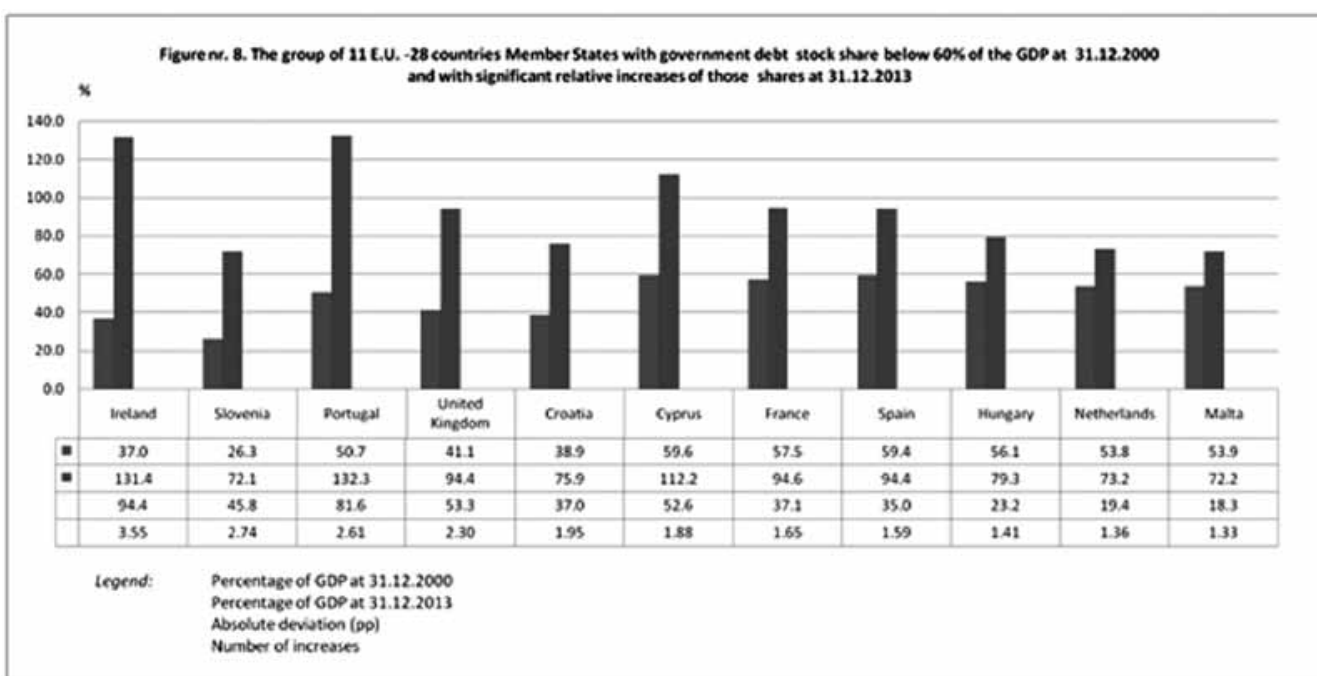

The government debt stock share in the GDP increased in Ireland in the analyzed period with $\mathbf{9 4 . 4}$ percentage points, with a relative deviation of $+255.1 \%$, compared to the registered value at 31.12 .2000 (37.8\%), i.e. a growth of 3.55 times of this share.

The government debt stock of Ireland increased in the analyzed period by 5.51 times - from 39,094.7 million Euros, at 31.12.2000, to 215,550.0 million Euros, at 31.12.2013, with an absolute deviation of $+176,455.9$ million Euros, whereas the absolute increase of the GDP represented only 58,275.2 million Euros (from 105,774.6 million Euros to 164,049.8 million Euros), which represents a growth of only 1.55 times.

The government debt stock share increased in Slovenia at 31.12.2013 by 45.8 percentage points, with a relative deviation of $+174.1 \%$, which represents a growth of 2.74 times of this share.

The absolute government debt stock of Slovenia increased by 4.64 times, with a deviation of $+19,944.5$ million euro - from 5,483.6 million Euros to 25,428.1 million Euros, whereas the GDP increased only by 13,741.5 million Euros, i.e. by only 1.64 times.

In Portugal, the government debt stock share in the GDP registered $132.3 \%$ at 31.12 .2013 and exceeded with 81.6 percentage points the share level at 31.12.2000 (50.7\%), which shows a growth of 2.74 times of this share.

The government debt stock of Portugal in absolute numbers increased by 3.39 times - from 64,640.5 million Euros at 31.12.2000, to 219,225.0 million Euros at 31.12.2013, with an deviation in absolute numbers of $+154,584.5$ million Euros, whereas the absolute deviation of the GDP increased by only 38,373.1 million Euros (from 127,316.9 million Euros to 165,690.0 million Euro), i.e. by only 1.3 times.

The government debt stock share of the GDP in the United Kingdom of Great Britain and Northern Ireland increased at the end of the analyzed period 
to $94.4 \%$, with 53.3 percentage points above the share level at $31.12 .2000(41.1 \%)$, with a relative growth of $129.7 \%$.

The absolute value of the government debt stock in the United Kingdom, of 1,792,797.2 million Euros at 31.12.2013, increased by 1,152,343.7 million Euros, compared to the minimum government debt stock of $640,453.5$ million Euros, at 31.12.2000, which means a growth of 2.8 times.

In the same time interval the evolution of the GDP registered an increase in absolute numbers of only 298,891.3 million Euros (from 1,600,206.7 million Euros, to $1,899,098.0$ million Euros), i.e. by only 1.19 times.

In Croatia, (E.U. Member State since July 1st 2013), the governmental debt stock share in the GDP grew significantly during the 14 year interval discussed here - from $38.9 \%$ to $75.9 \%$, that is 37 percentage points, meaning a relative increase of $95.1 \%$, that is 1.95 times.

In absolute numbers, the raise in the governmental stock debt totals 23,413.4 million Euros - from 9,345.5 million Euros to 32,758.9 million Euros, that is 3.51 times, while the GDP grew only 1.8 times, by 19,133.6 million Euros - from 23,994.3 million Euros to 43,127.9 million Euros.

In Cyprus, during the analyzed period, the governmental debt stock share in the GDP grew by $\mathbf{5 2 . 6}$ percentage points - from $59.6 \%$, to $112.2 \%$, meaning a relative increase of $88.3 \%$, that is 1,88 times.

As an absolute value, the governmental debt stock share of Cyprus grew by 12,587.9 million Euros - from 5,930.9 million Euros, to 18,518.8 million Euros, meaning an important increase by 3,12 times.

During the same time interval, the GDP of Cyprus grew by only 1.66 times, by 6,554.7 million Euros (from 9,949.0 million Euros to 16,503.7 million Euros).

In France, during the analyzed period, the governmental debt stock share in the GDP grew by 37.1 percentage points - from $57,5 \%$ to $94,6 \%$, by a relative deviation of $64.5 \%$, that is a 1.65 times increase.

The governmental debt stock share of France grew, during the analyzed period, by 1,081,513.9 million Euros - from 867,961.1 million Euros, to 1,949,475 million Euros, that is 2,25 times, and the GDP grew by only 620,248.6 million Euros (from 1,439,603.4 million Euros, to 2,059,852.0 million Euros), that is 1.43 times.

Spain recorded an increase of 35 percentage points of the GDP share of the governmental debt stock to 31.12 .2013 - from $59.4 \%$ to $94.4 \%$, with a relative increase of this share of $58.9 \%$, i.e. by 1.59 times.

As an absolute value, governmental debt stock share of Spain at 31.12.2013 was by 591,624 million Euros bigger than the one recorded at 31.12.2000, the growth being by 2.58 times - from 374,557.0 million Euros to 966,181.0 million Euros.

During the same interval, the GDP grew by only 1.62 times, by 393,081.0 million Euros, from 629,907.0 million Euros to 1,022,988.0 million Euros.

In Hungary, the governmental debt stock share in the GDP by 31.12.2013 grew to $79.3 \%$, that is 23.2 percentage points above the share recorded at 
31.12.2000 - which was by $56.1 \%$. The relative growth of this share was by $41.3 \%$, that is a 1.41 times growth.

As an absolute value, the governmental debt stock share of Hungary grew by 50,020.4 million Euros, that is 2.81 times - from 27,696.4 million Euros to $77,716.8$ million Euros, while the GDP grew only 1.95 times, by 47,613.3 million Euros, from 50,334.7 million Euros to 97,948.0 million Euros.

The governmental debt stock share in the GDP in the Netherlands grew to 31.12 .2013 by 19.4 percentage points against the one recorded at 31.12 .2000 (53.8\%), reaching $73.2 \%$, with a relative deviation of $+36.1 \%$, meaning an increase by 1.36 times.

During the 14 year interval of the analyzed period, the governmental debt stock of the Netherlands grew 1.91 times, by 210,728.0 million Euros - from $230,311.0$ million euros to 441,039.0 million euros, while the GDP grew only 1.44 times, that is $184,698.0$ million euros - from $417,960.0$ million euros to $602,658.0$ million euros.

In Malta the increase of governmental debt stock share in the GDP was by 18.3 percentage points - from $53.9 \%$ to $72.2 \%$, that is 1.33 times.

In absolute numbers, the governmental debt stock share growth of Malta was by $+2,587.0$ million Euros, that is 1.97 times - from 2,654.0 million Euros to 5,241.0 million Euros.

During the same time interval, the GDP grew only 1.66 times, by $2,884.8$ million Euros - from 4,377.8 million Euros to 7,262.6 million Euros.

8. Of the 28 states that constitute the European Union at the moment, only 3 Member States recorded decreases of GDP shares of governmental debt stocks at the end of 2013, compared to the end of 2000, with values presented in the table no. 6 below and illustrated by figure no.9:

Table 6: The situation of the E.U.-28 Member States which registered decreases of government debt stock shares in the GDP at 31.12.2013 as compared to 31.12.2000

\begin{tabular}{|c|l|r|r|r|r|}
\hline \multirow{2}{*}{ No. } & \multirow{2}{*}{$\begin{array}{c}\text { Member State of the } \\
\text { EU-28 countries }\end{array}$} & \multicolumn{2}{|c|}{$\begin{array}{c}\text { Share in the GDP of } \\
\text { governmental debt stock (\%) at: }\end{array}$} & \multicolumn{2}{|c|}{ Deviation } \\
\cline { 3 - 6 } & & 31.12 .2000 & 31.12 .2013 & absolute (pp) & relative (\%) \\
\hline 1 & Bulgaria & 72.5 & 18.9 & -53.6 & -73.9 \\
\hline 2 & Sweden & 53.9 & 39.1 & -14.8 & -27.5 \\
\hline 3 & Denmark & 52.4 & 45.8 & -6.6 & -12.6 \\
\hline
\end{tabular}

Sources of data: Eurostat (Annex no. 5) and author's own calculations 


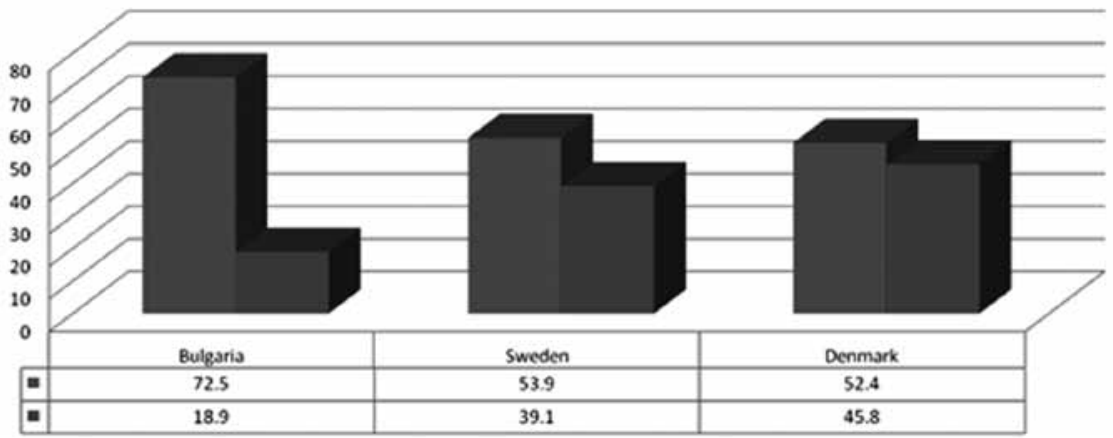

Of particular relevance is the significant decrease recorded in Bulgaria - from $72.5 \%$ to only $18.9 \%$, that is by 53.9 percentage points and a relative decrease of $73.9 \%$, given the fact that the GDP grew by $25,905.2$ million euros (from 14,035.1 million euros, to 39,940.3 million euros), that is by $184.6 \%$ ( 2.85 times). In the case of this E.U. Member State, a decrease in the absolute value of governmental debt could be noticed, by 2,635.5 million euros - from 10,168.5 million euros, to 7,532 million euros.

With such an evolution in the absolute sizes of the shares of governmental debt stock and of the GDP, and of the share of governmental debt stock share in the GDP, Bulgaria left the group of E.U. Member States that have an over $60 \%$ share of governmental GDP debt, as it was in 2000 and 2001 (when Bulgaria was not a member state of the EU), that it joined the group of EU Member States that have the lowest share of GDP governmental debt, coming on second place in the ranking of Member States that have the lowest public debt rate in the European Union (after Estonia, which, by 31.12.2013, has a share of governmental debt in the GDP of only $10.1 \%$ ).

In the case of Sweden, the GDP share of governmental debt stock decreased to 31.12 .2013 by 14.8 percentage points, compared to the share registered by 31.12.2000 (from 53.9\%, to 39.1\%), but the size of governmental debt stock increased by $26,152.4$ million euros, reaching the amount of $164,420.2$ million euros by 31.12 .2013 , compared to $138,267.8$ million euros by 31.12 .2000 , the relative growth being $+18.9 \%$ (that is 1.19 times). However, at the same time, the Gross Domestic Product registered an accentuated relative growth $(+56.9 \%$, that is 1.57 times), being by $+152,596.5$ million euros bigger by $31.12 .2013(420,849.1$ million euros, compared to 268,252.6 million euros).

Obviously, in the case of this member state, part of the 28 countries large EU, the GDP growth was progressive compared to the increase in governmental debt stock. Denmark is included in the group of EU Member States that meets the euro convergence criteria established by the Maastricht Treaty, but is not a 
member of the Euro Zone, as the Danish did not accept to join this zone, out of respect for their cherished „crown” as national currency.

The decreasing evolution of the GDP share of governmental debt stock in the case of this EU member state is of lesser dimension (6,6 percentage points, with a relative reduction of $-12.6 \%)$, but still an important one, being registered under the circumstances of an increase in governmental debt stock by $21,014.5$ million euros (from 93,084 million euros, to 114,098.5 million euros), that is by $22.6 \%$ (1.23 times) of a GDP increase of 75,377 million euros (from 173,597.8 million euros, to $248,974.8$ million euros) - a more accentuated one, that is by $43.4 \%$, in relative terms (1.43 times).

9. Of the entire $28 \mathrm{EU}$ Member States, by 31.12.2013, with GDP shares under $60 \%$ of governmental debt stock, in decreasing order of shares, the following 12 states can be mentioned: Estonia (10.1\%), Bulgaria (18.9\%), Luxembourg (23.5\%), Latvia (38.0\%), Romania (38.1\%), Sweden (39.1\%), Lithuania (39.4\%), Czech Republic (45.6\%), Denmark (45.8\%), Slovakia (55.7\%), Poland (57.27\%) and Finland (58.2\%).

According to a prior analysis, in 3 Member States (Bulgaria, Sweden and Denmark) out of the 12 Member States mentioned, a decrease in the GDP share of governmental debt stock could be noted. As a consequence, there are still 9 Member States where the GDP share of governmental debt stock increased by 31.12.2013, and the value in absolute numbers of this stock is also bigger than the one recorded by 31.12 .2000 .

For these 9 Member States of the 28 countries EU, the data corresponding to an ascending evolution of the GDP share of governmental debt stock are shown in table no. 7 and illustrated in figure no. 10.

Table 7: The upward evolution of government debt stock shares in the GDP, in the EU-28 countries Member States with shares below 60\% in the GDP at 31.12.2013

\begin{tabular}{|r|l|r|r|r|r|r|}
\hline \multirow{2}{*}{ No. } & \multirow{2}{*}{$\begin{array}{c}\text { Member state } \\
\text { of the EU-28 } \\
\end{array}$} & \multicolumn{1}{c|}{\begin{tabular}{c} 
countries \\
\cline { 3 - 6 }
\end{tabular}} & \multicolumn{2}{|c|}{$\begin{array}{c}\text { GDP share of governmental } \\
\text { debt stock (\%) by: }\end{array}$} & \multicolumn{2}{|c|}{$\begin{array}{c}\text { Times } \\
\text { of share } \\
\text { increase }\end{array}$} \\
\hline 1 & Luxembourg & 6.2 & 23.5 & +17.3 & +279.0 & 3.79 \\
\hline 2 & Latvia & 12,4 & 38.0 & +25.6 & +206.5 & 3.06 \\
\hline 3 & Czech Republic & 17.8 & 45.6 & +27.8 & +156.2 & 2.56 \\
\hline 4 & Estonia & 5.1 & 10.1 & +5.0 & +98.0 & 1.98 \\
\hline 5 & Romania & 22.5 & 38.1 & +15.6 & +69.3 & 1.69 \\
\hline 6 & Lithuania & 23.6 & 39.4 & +15.8 & +66.9 & 1.67 \\
\hline 7 & Poland & 38.3 & 57.2 & +18.9 & +49.3 & 1.49 \\
\hline 8 & Finland & 43.8 & 58.2 & +14.4 & +32.9 & 1.33 \\
\hline 9 & Slovakia & 50.3 & 55.7 & +5.4 & +10.7 & 1.11 \\
\hline
\end{tabular}

Sources of data: Eurostat (Annex no. 5,6 ) and author's own calculations 


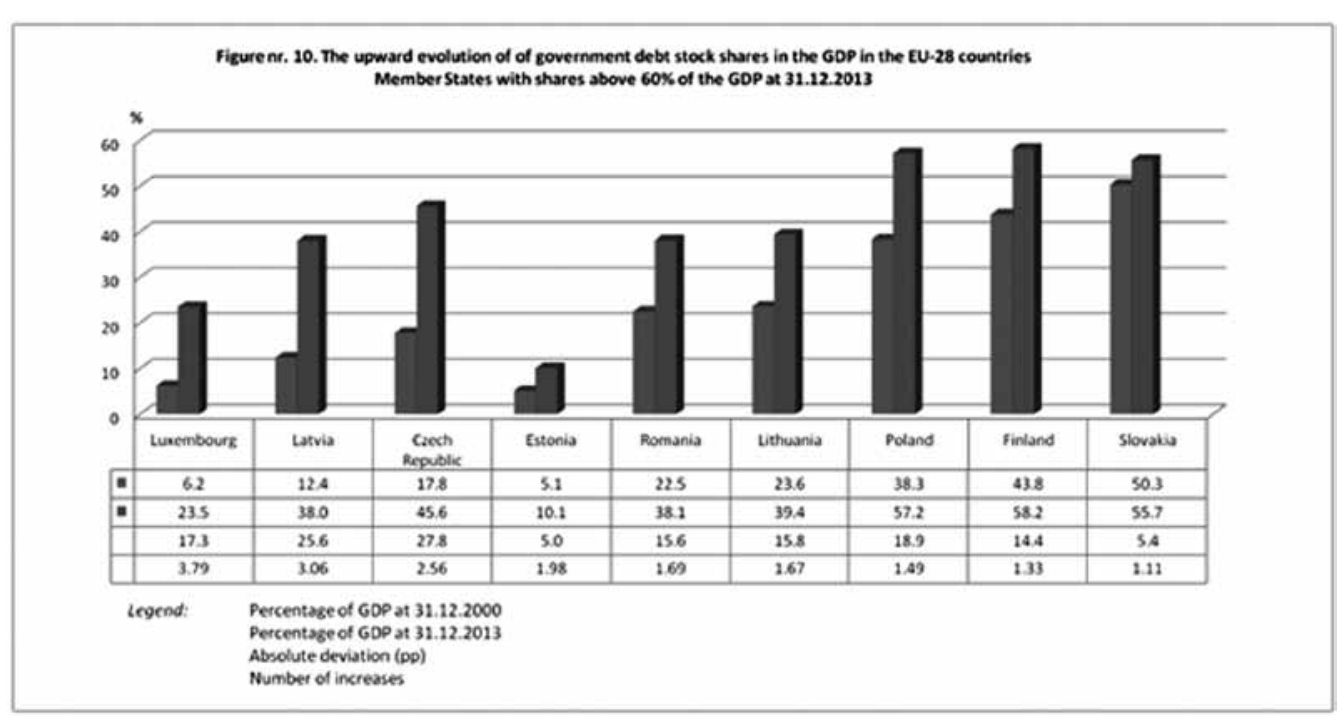

Absolute deviations in the case of this group of E.U. Member States range between +27.8 percentage points in the case of the Czech Republic and 5.0 percentage points - in the case of Estonia, and relative deviations range between $+279.0 \%$ - in the case of Luxembourg and only $+10.7 \%$ - in the case of Slovakia.

If we take into account the GDP share of governmental debt stock by 31.12.2013, then the order of the 9 Member States changes significantly, as follows: Finland (58.2\%), Poland (57.27\%), Slovakia (55.7\%), Czech Republic (45.6\%), Lithuania (39.4\%), Romania (38.1\%), Latvia (38.0\%), Luxembourg (23.5\%) and Estonia (10.1\%).

In absolute numbers, the deviations of governmental debt stock, in descending order, are as follows in table no. 8 and illustrated in figure no. 11.

Table 8: Absolute deviations and times of increases of government debt stocks in the EU-28 countries Member States with shares below 60\% in the GDP

\begin{tabular}{|r|l|r|r|r|r|}
\hline \multirow{2}{*}{ No. } & \multirow{2}{*}{$\begin{array}{c}\text { Member state of the } \\
\text { EU-28 countries }\end{array}$} & \multicolumn{2}{|c|}{$\begin{array}{c}\text { Share of governmental debt } \\
\text { stock (mill. Euros) by: }\end{array}$} & $\begin{array}{c}\text { Absolute deviation } \\
\text { (mill. Euros) }\end{array}$ & $\begin{array}{c}\text { Times of stock } \\
\text { increase }\end{array}$ \\
\cline { 3 - 4 } & & 31.12 .2000 & \multicolumn{1}{|c|}{31.12 .2013} & & \\
\hline 1 & Poland & $71,128.9$ & $222,926.4$ & $+151,797.5$ & 3.13 \\
\hline 2 & Czech Republic & $11,525.8$ & $68,152.2$ & $+56,626.4$ & 5.91 \\
\hline 3 & Finland & $57,926.2$ & $112,664.0$ & $+54,737.8$ & 1.94 \\
\hline 4 & Romania & $7,532.8$ & $54,170.0$ & $+46,637.2$ & 7.19 \\
\hline 5 & Slovakia & $10,753.4$ & $40,178.4$ & $+29,425.0$ & 3.74 \\
\hline 6 & Lithuania & $2,912.1$ & $13,636.5$ & $+10,724.4$ & 4.68 \\
\hline 7 & Luxembourg & $1,410.3$ & $10,668.9$ & $+9,258.6$ & 7.57 \\
\hline 8 & Latvia & $1,011.0$ & $8,876.0$ & $+7,865.0$ & 8.78 \\
\hline 9 & Estonia & 315.6 & $1,887.5$ & $+1,571.9$ & 5.98 \\
\hline
\end{tabular}

Sources of data: Eurostat (Annex no. 3,4) and author's own calculations 


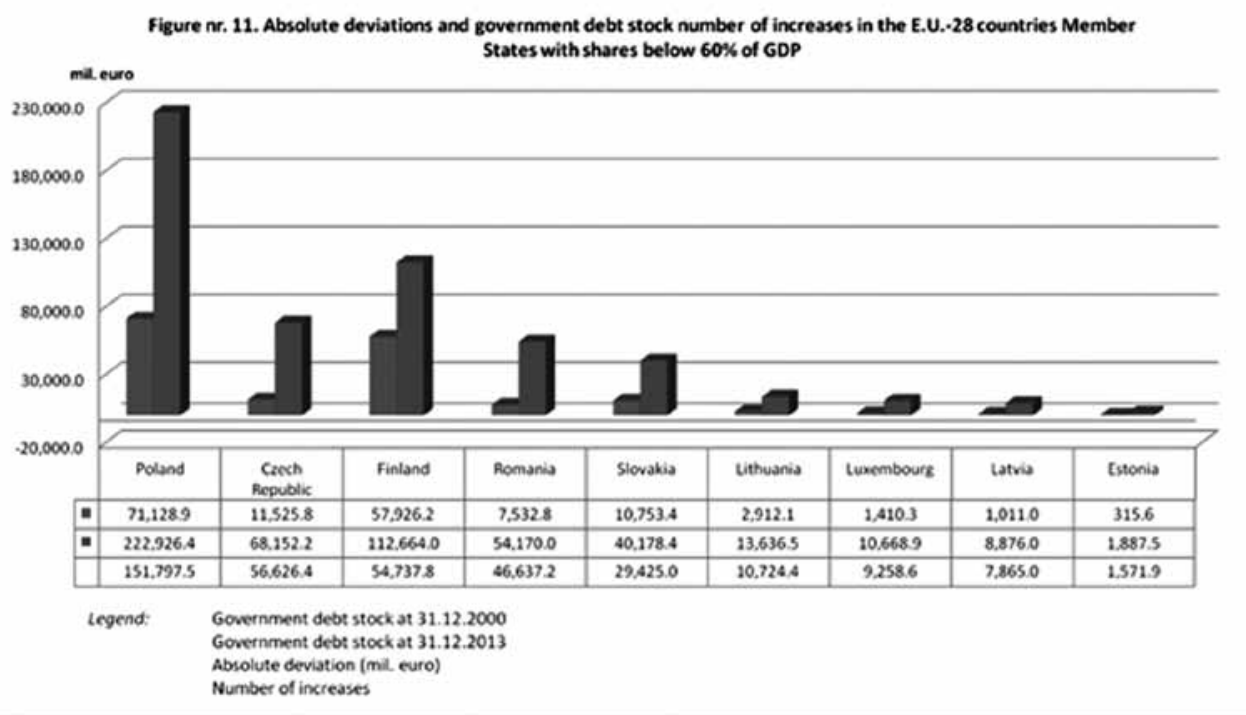

As it can be noticed, the order size of governmental debt stock and of absolute deviation registered vary a lot from one member state to another, with governmental debt stocks ranging from 315.6 million Euros (Estonia by 31.12.2000) and 222,926.4 million Euros (Poland by 31.12.2013, that is 706.4 times the size of Estonia's governmental debt stock by 31.12.2000).

With regard to the increase in number of times of governmental debt stock, the order of Member States is completely different than the one registered in the previous table, as it can be seen in the last column of the table. Therefore, this decreasing order is as follows: Latvia (by 8.78 times), Luxembourg (by 7.57 times), Romania (by 7.19 times), Estonia (by 5.98 times), the Czech Republic (by 5.91 times), Lithuania (by 4.68 times), Slovakia (by 3.74 times), Poland (by 3.13 times) and Finland (by 1.94 times).

10. The analysis of the consolidated governmental debt of Romania was made on the basis of data registered at the end of the 56 quarters of the 14 year interval of the period 2000-2013, presented in table no. 9 and illustrated by figures no. 12 and no. 13. 
Comparative analysis of government debt in the European union's member... 101

Table 9: The consolidated government debt of Romania, expressed in million Euros and in percentage of the GDP at the end of the quarters in the period 01.01.2000-31.12.2013

\begin{tabular}{|c|c|c|c|c|c|c|c|c|}
\hline Years & \multicolumn{3}{|c|}{ The consolidated governmental debt stock } & \multicolumn{4}{c|}{$\begin{array}{c}\text { The GDP share of consolidated } \\
\text { in million Euros }\end{array}$} \\
\hline & Q1 & Q2 & Q3 & Q4 & Q1 & Q2 & Q3 & Q4 \\
\hline 2000 & $7,258.6$ & $7,372.4$ & $7,535.2$ & $7,532.8$ & 23.7 & 24.2 & 22.9 & 22.5 \\
\hline 2001 & $8,573.6$ & $9,668.7$ & $9,285.4$ & $10,917.2$ & 24.7 & 25.5 & 25.0 & 27.3 \\
\hline 2002 & $9,994.3$ & $9,718.6$ & $10,175.5$ & $10,757.1$ & 25.0 & 26.5 & 25.5 & 26.8 \\
\hline 2003 & $10,165.0$ & $10,333.3$ & $10,414.4$ & $10,309.5$ & 24.9 & 24.7 & 23.5 & 22.8 \\
\hline 2004 & $10,764.2$ & $11,331.7$ & $11,697.0$ & $11,768.7$ & 22.6 & 22.3 & 21.7 & 19.7 \\
\hline 2005 & $11,513.3$ & $12,844.1$ & $12,492.1$ & $12,397.7$ & 17.4 & 17.6 & 16.3 & 16.0 \\
\hline 2006 & $12,284.7$ & $11,753.6$ & $11,884.9$ & $12,585.6$ & 15.3 & 14.7 & 15.0 & 13.3 \\
\hline 2007 & $13,287.7$ & $14,113.2$ & $13,737.4$ & $14,763.0$ & 14.1 & 13.8 & 13.6 & 13.9 \\
\hline 2008 & $14,262.8$ & $14,677.7$ & $14,955.4$ & $17,158.6$ & 14.1 & 13.0 & 12.5 & 13.6 \\
\hline 2009 & $19,429.7$ & $21,002.7$ & $25,650.3$ & $27,955.5$ & 16.4 & 17.4 & 21.7 & 23.0 \\
\hline 2010 & $32,731.5$ & $32,864.1$ & $34,607.4$ & $37,426.2$ & 26.4 & 27.9 & 28.4 & 29.5 \\
\hline 2011 & $39,806.3$ & $43,123.3$ & $41,955.8$ & $44,675.1$ & 30.5 & 33.3 & 32.1 & 32.4 \\
\hline 2012 & $48,242.8$ & $47,199.9$ & $46,617.9$ & $50,128.1$ & 35.8 & 34.8 & 34.3 & 38.0 \\
\hline 2013 & $52,062.1$ & $52,324.4$ & $53,540.2$ & $54,170.0$ & 38.7 & 38.8 & 39.2 & 38.1 \\
\hline
\end{tabular}

Sources of data: Eurostat Date of extraction: 22/04/2013 for the period 01/01/2000-30/09/2012, 20/11/2014 for the period 01/10/2012-31/12/2013.

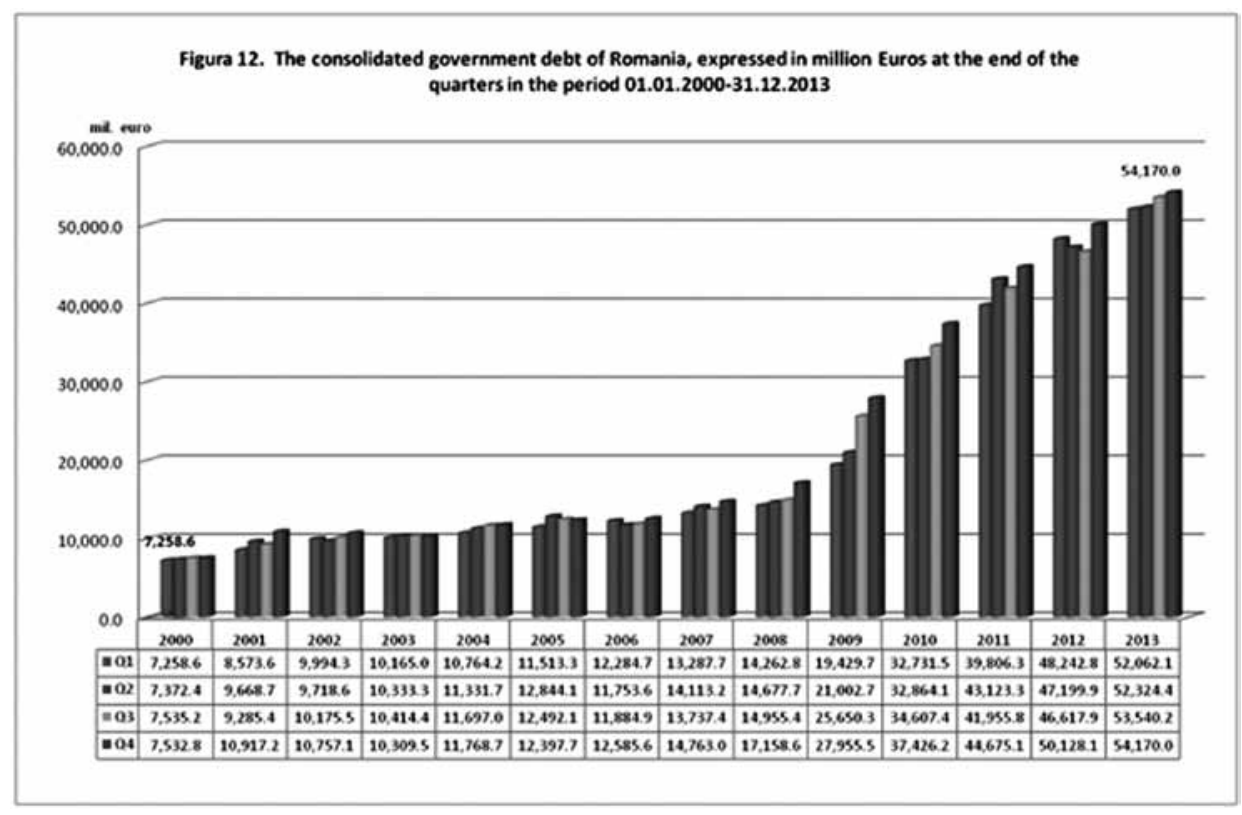

Vol. 11, No 4, 2014: 83-108 


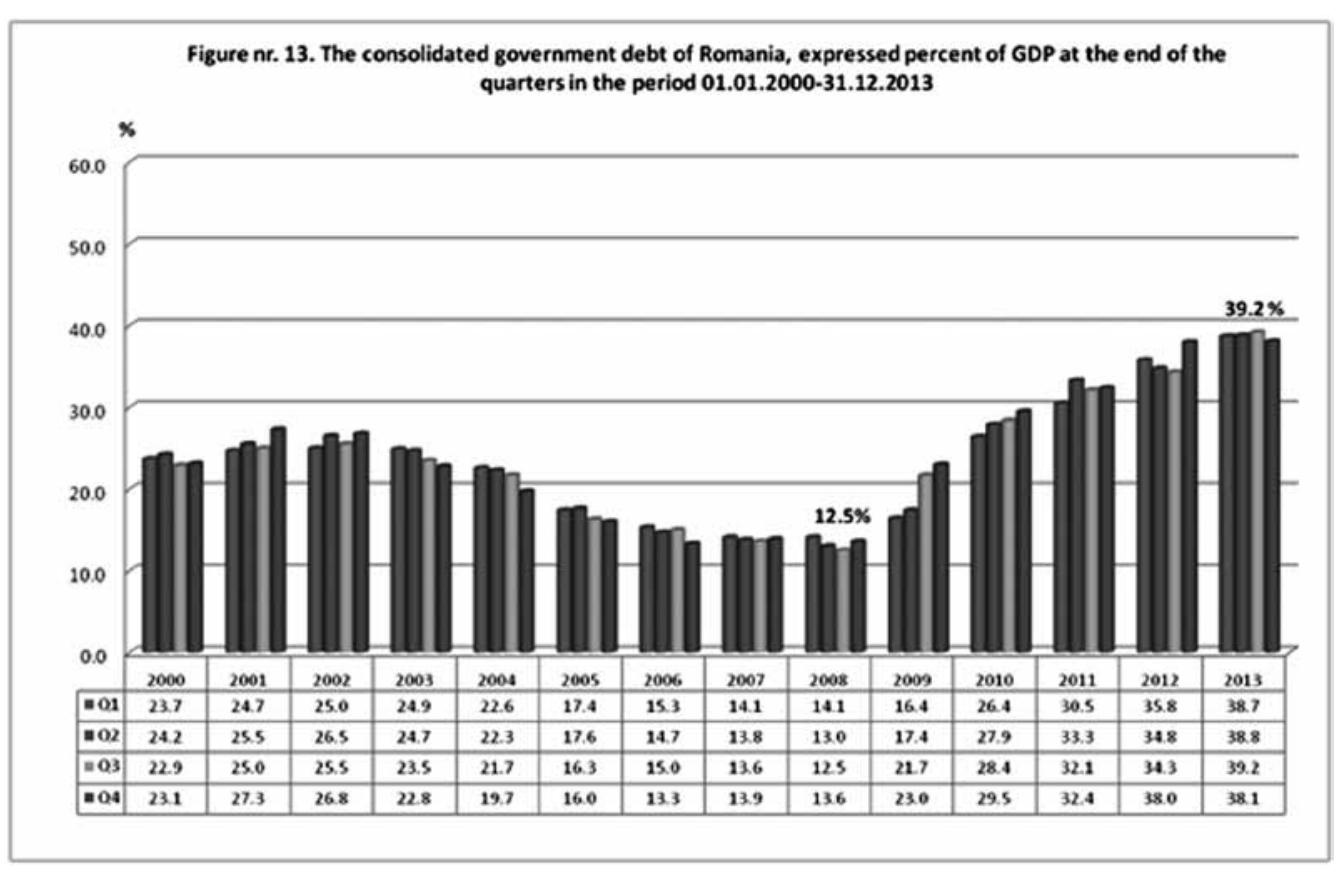

As it can be observed, in the time interval analyzed here, the GDP share of consolidated governmental debt stock varied between $12.5 \%$ by 30.09 .2008 and $39.2 \%$ by 31.03 .2012 , therefore, taking into account this UEM criteria of convergence, established by the Maastricht Treaty, Romania did not go through a crisis of governmental debt!

But..., the maximum stock of governmental debt, totalling 54,170.0 million Euros, registered by 31.12.2013, has increased 7.46 times against the minimal stock of governmental debt, totalling 7.258,6 million Euros, registered by 31.03.2000, it being 46,911.4 million Euros bigger.

At the same time, the GDP of Romania grew by 101,593.8 million Euros (from 40,651.3 million Euros, to 142,245.1 million Euros), this being a significant increase by 3.5 times.

The deviation between the two GDP shares of maximum and minimum stock of governmental debt at the end of the analyzed trimesters is of $\mathbf{1 4 . 4}$ percentage points, which, in a relative expression, means a significant increase of $60.8 \%$, that is 1.61 times.

In absolute numbers, the consolidated governmental debt stock of Romania increased almost continuously, with small minus variations at the end of some quarters (quarter 4 of the year 2000, quarter 3 of the year 2001, quarter 2 of the year 2002, quarter 4 of the year 2003, quarters 3 and 4 of the year 2005, quarter 2 of the year 2006, quarter 3 of the year 2007, quarter 3 of the year 2011 and quarter 3 of the year 2012). 
The accentuation of the increase of the governmental debt stock began during quarter 4 of the year 2008, that is after the previous quarter registered the smallest GDP share of governmental debt stock (12,5\%). From this minimal share, the evolution was marked by a solid increase, reaching a maximum share of $39.2 \%$, registered at 30.09 .2013 , with an absolute deviation of 26.7 percentage points, which means a relative increase of $213.6 \%$, that is an "unhealthy" increase of 3.14 times, given the fact that by the end of the year 2009, the economic crisis was completely "imported" into Romania as well.

Given this background, in the year 2010, Romania had to contract major loans, including from the International Monetary Fund, in order to be able to sustain salary payments in the budget sector and payments for state social insurance and other forms of social protection.

Doubtlessly, the increase of governmental debt stock in order to finance consumption is an error and it needs to be avoided in the future. Otherwise, if Romania's public debt continues in the rhythm registered since 2009, the $60 \%$ GDP limit of public debt would be surpassed in a short period of time and Romania would be faced with a crisis of governmental debt too!

\section{Conclusions}

The comparative detailed analysis of the evolution of governmental debt stock at the end of each year in the EU Member States revealed the following aspects:

- The evolution of governmental debt stock has increased: at the level of 28 EU countries, EU-27 countries, the Euro area including 17 Member States and 18 Member States, the Non-Euro area with 10 Member States and with 11 Member States and in 27 Member States of the EU (except for Bulgaria);

- $\quad$ in 3 EU Member States (Bulgaria, Sweden and Denmark) there was a decrease of the GDP share of governmental debt stock, one of these states (Bulgaria) exiting the group of E.U. Member States that have a public debt bigger than $60 \%$ of the GDP - it was part of it at the beginning of the analyzed interval (31.12.2000);

- $\quad$ at the end of the analyzed interval (31.12.2013), the limit of over $\mathbf{6 0 \%}$ of the GDP was reached by the sums of effective stock of governmental debt:

- at the level of the entire European Union, with a share of $90.2 \%$, compared to $62.7 \%$ by 31.12 .2000 ;

- at the level of the Euro region comprising 18 Member States and 17 Member States, with shares of $96.2 \%$ and $96.4 \%$, compared to $70.2 \%$ and $70.3 \%$, by 31.12 .2000 ; 
- at the level of the Non-Euro area with 10 Member States and with 11 Member States, with a share of $73.2 \%$ and $73.3 \%$, compared to $41.6 \%$ in both areas, by 31.12.2000;

- in 16 EU Member States of the EU-28, compared to only 6 Member States of the EU-28 by 31.12.2000;

- in all 16 Member States registering significant public debt there was an increase in the GDP share of governmental debt stock varying between 94,4 percentage points (in Ireland) and 0.2 percentage points (in Belgium);

- very high absolute and relative deviations (between $+255.1 \%$ and $+58.9 \%)$ of the GDP share of governmental debt stock were registered in 9 Member States of the EU-28 (Ireland, Slovenia, Portugal, United Kingdom, Croatia, Cyprus, Greece, France and Spain), with increases in the size of governmental debt stock between 5.51 times (in the case of Ireland) and 2.25 times (in the case of France);

- in 15 Member States of the EU-28 countries out of 16 Member States that have an over 60\% GDP rate of governmental debt by 31.12.2013, the increase in the absolute sum of governmental debt stock, from the beginning until the end of the analyzed time interval, surpassed the growth in absolute sums of the GDP, excepting Malta, in which case the deviation in absolute sum was over 2,587.0 million Euros, impacting the share growth in the GDP of governmental debt stock;

- in the year 2009, GDP registered decreases in absolute numbers, compared to 2008 :

- at the level of the entire European Union - EU-28 countries and EU-27 countries;

- at the level of the 2 Euro areas with 18 Member States and with 17 Member States;

- at the level of the 2 Non-Euro areas with 10 Member States and with 11 Member States;

- in all 28 Member States of the EU;

- in the year 2010, compared to the year 2009, decreases in the size of the GDP were registered in 5 Member States of the EU-28 countries (Ireland, Greece, Spain, Croatia, Latvia);

- in the year 2011, compared to the year 2010, decreases in the size of the GDP were registered in only 3 Member States of the EU-28 countries (Greece, Croatia, Portugal);

- decreases in the size of the GDP were registered in the year 2012, compared to the year 2011, but only in 9 Member States of the EU-28 countries (Czech Republic, Greece, Spain, Croatia, Italy, Cyprus, Slovenia, United Kingdom), 6 of these states being part of the group of 16 E.U. Member States with high public debt; 
- Greece and Croatia registered decreases in the size of the GDP in 5 consecutive years (2009, 2010, 2011, 2012 and 2013);

- in 5 Member States of the EU-28 countries (Czech Republic, Spain, Italy, Cyprus, Slovenia) there were decreases in the size of the GDP 3 years after the year 2008 (2009, 2012 and 2013);

- in the case of Romania, the evolution of the size of consolidated governmental debt stock has increased significantly, registering a deviation in absolute numbers of $+46,911.2$ million Euros by 31.12.2013, compared to the one registered at the end of the first trimester of the year 2000, an increase of 7.46 times;

- against the background of an accentuated growth in the size of Romania's GDP - that in absolute numbers was by 3.5 times bigger at 31.12.2013, compared to the size of the GDP by 31.12.2000, the GDP share of governmental debt stock has increased by only 15.6 percentage points, that is 1.69 times;

- $\quad$ under these circumstances, with a GDP share of governmental debt stock of $38.1 \%$ by 31.12 .2013 , Romania comes 5 th among the states with the least public debt of the 28 Member States of the EU-28 countries (after Estonia - 10.1\%, Bulgaria - 18.9\%, Luxembourg - $23.5 \%$ and Latvia - 38.0\%). 


\section{Literature}

- $\quad$ Traité de Maastricht, 7 février 1992, art. 121;

- Berg, A., Krueger, A., 2003, Trade, Openness and Poverty: A Selective Survey, IMF Working Paper no. 03/30. Washington, DC: International Monetary Fund;

- Talpoş, Ioan, Deficitul bugetar structural şi datoria publică a României, Conferința internațională „Efecte ale crizei actuale asupra economiei globale”, în Analele Universității „Ovidius” din Constanța, Seria economică, vol. XII, nr.2/2012 (Structural Budget Deficit and Romania's Public Debt, International Conference „Effects of the Current Crisis upon Global Economy” in the Annals of the „Ovidius” University of Constanța, Economics Series, vol. XII, no.2/2012);

- Talpoş, Ioan, La crise de la dette publique dans les États membres de l'Union Européenne, 58 ${ }^{\text {ème }}$ Congrès de l'AIELF - Valladolid, 19-22 mai 2013, in: Procedia published in electronic format;

- Talpoş, Ioan, Disertație la conferirea titlului Doctor Honoris Causa de către Universitatea Valahia din Târgovişte - „Analiza evoluției datoriei guvernamentale în statele membre ale Uniunii Europene în perioada 2000-2012", 10.06.2013; (Disertation at the Award Ceremony for the title of Doctor Honoris Causa by the Valahia University of Târgovişte - „Analysis of Governmental Debt Evolution within E.U. Member States, 2000-2012”);

- (Eurostat database, data retrieved 22.04.2013, 14.11.2014 and 20.11.2014);

- http://epp.Eurostat.ec.europa.eu/portal/page/portal/Eurostat/home/;

- http://fr.wikipedia.org/wiki/Trait\%C3\%A9_sur_1\%27Union_europ\%C3\%A9enne.

Paper received: November $18^{\text {th }}, 2014$

Approved for publication: November $28^{\text {th }}, 2014$
Rad primljen: 18. novembar 2014. Odobren za štampu: 28. novembar 2014. 


\section{UPOREDNA ANALIZA JAVNOG DUGA ZEMALJA ČLANICA EVROSPEK UNIJE, 2000 - 2013}

\section{S a ž e $\mathbf{t}$ a $\mathbf{k}$}

Rad daje detaljnu komparativnu analizu razvoja akcija javnog duga kod država članica Evropske unije na kraju perioda 31.12.2000-31.12.2013 sa tačke gledišta učešća ovih dugova u BDP, sa posebnim osvrtom na šest grupa članica Evropske unije (EU - 28 zemalja, EU - 27 zemalja, Evrozona - 18 zemalja, Evrozona - 17 zemalja, zemlje koje nisu u Evrozoni - 10 zemalja, zemlje koje nisu u Evrozoni - 11 zemalja), zemlje članice Evropske unije sa udelom akcija javnog duga iznad ili ispod 60\% BDP-a na dan 31. 12. 2013, zemlje članice kod kojih su zabeležene velike devijacije akcija javnog duga i udela tih akcija u BDP u posmatranom periodu, ili one koje su zabeležile smanjenje akcija javnog duga u BDP, kao i posebnim osvrtom na Rumuniju.

Ključne reči: javni dug, akcije javnog duga, akumulacija javnog duga, javna zaduženost, povećanje akcija javnog duga, bruto domaći proizvod, apsolutna devijacija, relativna devijacija, periodi povećanja, kriza javnog duga 
